\title{
Perceptions of Academic Staff on Causes of Plagiarism in Project Writing Among Undergraduate in Southwest Nigeria
}

\author{
Olusanya Francis Olufemi ${ }^{1}$, Buraimo Olayinka $a^{1,}$, , Oyedokun Siddiqah Olatope ${ }^{1}$, \\ Ogunsanya Adeola Oladele ${ }^{2}$, Ajani Florence Olabisi ${ }^{3}$ \\ ${ }^{1}$ University Library, Olabisi Onabanjo University, Ago-Iwoye, Nigeria \\ ${ }^{2}$ Department of Arts and Social Science Education, Olabisi Onabanjo University, Ago-Iwoye, Nigeria \\ ${ }^{3}$ University Library, Kwara State University, Malete, Nigeria
}

Email address:

Folusanya69@gmail.com (O.F. Olufemi),waleola19601@gmail.com (B. Olayinka), siddiqaholatope@gmail.com (O. S. Olatope), droladeleogunsanya@gmail.com (O. A. Oladele), florence.ajani@kwasu.edu.ng (A. F. Olabisi)

${ }^{*}$ Corresponding author

\section{To cite this article:}

Olusanya Francis Olufemi, Buraimo Olayinka, Oyedokun Siddiqah Olatope, Ogunsanya Adeola Oladele, Ajani Florence Olabisi. Perceptions of Academic Staff on Causes of Plagiarism in Project Writing Among Undergraduate in Southwest Nigeria. American Journal of Information Science and Technology. Vol. 4, No. 4, 2020, pp. 58-66. doi: 10.11648/j.ajist.20200404.11

Received: November 20, 2020; Accepted: December 7, 2020; Published: December 16, 2020

\begin{abstract}
Despite knowledge and awareness of plagiarism among undergraduates through the teaching of related compulsory university course for all students as well as teaching of research methodology in various field in Nigeria universities, final year students sill found plagiarized while writing their research work. It was based on the above, that this study was design to explore the perception of the academic in Southwest Nigeria on the causes of plagiarism among final year undergraduates while writing their research project. The study makes use of descriptive survey research design of expo factor type where eighteen universities were selected with a total sample of 1,800. Data were collected through questionnaire and analysed using both the descriptive and quantitative analysis. The findings indicated among others that laziness, lack of knowledge about plagiarism, lack of experience among students in producing source-based writing and lack of adequate skill to write final year project were some of the perceived causes of plagiarism in project writing. Moreso, incompetent graduate, injustices in grading student's projects were some of the effect of plagiarism. Similarly, awareness campaign and theuse of plagiarism checker among others were some of the perceived measured that can be adopted in solving the menace of plagiarism among students.
\end{abstract}

Keywords: Academic Staff, Plagiarism, Project Writing, Southwest, Nigeria

\section{Introduction}

\subsection{Background to the Study}

Academic institutions all over the world have been saddled with the responsibilities of engaging in teaching, research and community service. Apart from research being carried out by members of staff in academic institutions, undergraduates also carry out research in their chosen discipline or course of study which serve as major prerequisite for graduation. Student's research in this regard, add to existing body of knowledge and are readily available for usage at any point in time. Therefore, the authenticity of such research is paramount to research and educational development in general. For students to be awarded a degree in any academic institutions, they must undertake a major research project in their final year [1]. The author further opined that, undergraduate students need to execute such major project to demonstrate their overall capability before graduating from the system. This is a significant challenge for students in most cases, being relatively student-driven and free-format, and being in assessment terms. In this aspect, students are on their own and are only guided by their instructor or project supervisor. Since the final year project in this case is not a written examination per se, students most often get readymade project work by another students or 
researchers. This is possible as a result of information explosion and availability of internet anywhere, anytime and anyhow. Thus, personal information are replaced on such work to their supervisor for approval and when this happens, and if care is not taken, such students will submit the work and graduate from the institution. Then, what knowledge and contributions has such student provided in terms of the research responsibility of academic institutions? In similar vein, it has been affirmed that many undergraduate students, while writing their final year project, copy a lot from other people's research reports without due acknowledgement [2]. This implies that such students lack the capacity to carry out research work and report the research work required of them for graduation. This act is referred to as plagiarism and it has a lot of adverse effect on students, educational sector, growth and development of education and personality.

Studies on plagiarism and other academic misconduct among students in tertiary institutions had been documented locally and internationally over the years. For instance, researchers both local and international have stressed that plagiarism and other forms of academic injustice and misconduct is a complex phenomenon and a common occurrence among undergraduates in one form or the other [2-6]. The ubiquity of plagiarism among undergraduates all over the world has been found to depend on information explosion that is aided by the internet and abundant media technologies which have made it very easy for undergraduates in tertiary institutions to gain access to information needed with ease anytime and whenever they need it. Research on the knowledge, awareness, causes and effect of plagiarism have also been documented. Researchers have documented that undergraduates in tertiary institution all over the continents are aware and knowledgeable about plagiarism, it adverse effect on students, economy as well as standard of education [5-7].

\subsection{Statement of the Problem}

Despite various documentation about undergraduates 'awareness, knowledge, causes and effect of plagiarism and other forms of academic misconducts as well as the fact that plagiarism is considered a criminal act, it is noteworthy that final year students who had been in the university for over three (3) years and above, depending on their course of study, and had in one way or the other been taught about plagiarism, still plagiarize most especially while writing their final year project [5-7]. In many university in Nigeria, plagiarism as a sub-topic had been taught in first year during the teaching of General Study Skill and ICT (GNS 102) and also as a subtopic in the university curriculum across different discipline in the university during the teaching of research methodology. Inspite of this, final year students are still found plagiarizing while writing their research project or final year research work by either copy the whole research as he or she was the original author or copy substantive portion of the work without due acknowledgement. This act of academic theft had brought about serious concern to management of tertiary institutions, lecturers, educational expert and researchers amongst others as a result of dangers inherent in this academic misconduct and the aftermath effect of such act. Hence, in order to address the menace of plagiarism among undergraduates and most especially while writing final year project, there is need to seek the opinion of the academic staff on what they think are the causes of plagiarism among final year students in project writing so as to proffer lasting solution towards combating the incidence of plagiarism and other forms of academic dishonesty in our campuses.

A search through literature on plagiarism among students in tertiary institution across the globe indicated that most studies on plagiarism were carried out using all categories of students in the university irrespective of level of study. There is paucity of research on plagiarism among final year's students in project writing [7-10]. Similarly, study of this kind is scarce in literature in Nigeria using the State, Federal and Private University. This is the Gap the researchers of this study intended to fill. It is based on the gap above, that this study was designed to examine the perceptions of academic staffs on the causes of plagiarism in project writing among final year undergraduates in Southwest, Nigeria.

\section{Literature Review}

\subsection{Meaning of Plagiarism}

Plagiarism is a Latin word 'plagiarius' which means to forcefully take another person ideas or work and claim to be his. Plagiarism is considered as the practice of using other people's ideas and works without acknowledging the sources and passing it as one's own works $[3,5]$. Plagiarism is also referred to as dishonest academic behavior by taking either literal or similar characteristics of text, changing it with its synonym or reversing to both submissive and vigorous sentence without acknowledging or give credit to original authors [11]. Moreso, plagiarism refers to the act of putting someone's else or one's name on someone else work without authorization [8, 12]. Plagiarism can be described as fraudulent behaviour or theft that diminishes the Intellectual property of the original author and rewards plagiarists for their work [13]. Similarly, plagiarism is regarded as a situation whereby one utilizes another person's words or ideas without proper credit [14].

\subsection{Perceived Causes of Plagiarism}

There are various reasons that encouraged plagiarism among final year undergraduates most especially while writing their final year project (long essay). It was indicated that inadequate time, improper teaching of Research method, ignorance, absence of a university policy among others are the major causes of plagiarism by students while writing their project [2]. According to other researchers, undergraduates plagiarized due to laziness, ignorance about plagiarism, inadequate time, expensiveness of project write-up, inappropriate teaching of research methodology and lack of adequate supervision by the project supervisor [15-17]. 
In a recent study conducted in Nigeria, the authors affirmed the desire to achieve high marks, fear of failure and poor academic planning as the major reasons for engaging in plagiarism [5]. Similarly, it was reported that most students plagiarize because they want to avoid lower levels of GPAs, lower levels of school identification and they also lack adequate proficiency in English Language [18]. In addition, plagiarism occurs due to pressure of work to get certain level of academic degree and also due to incapability of writing an academic paper or research work [11]. Moreso, access to internet, shortage of books, laziness among students and poor academic writing skills has also be reported as key factors that promote plagiarism among students [12]. To some other researchers, easy and cheap access to a surplus of academic sources on the internet were reported as the most cogent reason that encourage plagiarism among undergraduates [19, 22].

Furthermore, various reasons had been pointed out as the key determinants of plagiarism. For this, student plagiarized when they are not well integrated in the academic community culture in particular, lack orientation on ethics of academia, when they are studying as well as working (part-time students), parental pressure that demand them to perform well, when they lack study skills as well as good studentlectures relationship, when they noticed that lecturers are unlikely to punish them for academic dishonesty [23]. Moreso, inexperienced in producing source-based writing is also considered as another reason for plagiarism [24]. Similarly, another reason for plagiarism among students is when students do not have a clear understanding of what constitutes plagiarism and how it can be avoided [25].

Consequently, there are ten major reasons why students plagiarize [26]. According to the researcher, students plagiarized as a result of laziness, fear of failure, inconfidence on part of the students, Lack of knowledge development, students unwillingness to understand and digest original materials to a meaningful statement, lack of understanding of important content related to own study, carelessness on part of students, students refusal in understanding why sources are important, sloppiness, failure to understand how to deal with citations, novelty and familiarity to a collaborative work model.

\subsection{Perceived Effect of Plagiarism}

Effect of plagiarism can be grouped into four (04) major categories. This includes: individuals, moral, specialized, and lawful. As a result of plagiarism software that is readily available everywhere, it is now very easy to detect anyone who plagiarized and this has also made it easy to detect high rate of plagiarism and other academic misconduct. In this regard, any one or person found plagiarism will face the consequences of his or her action. Ignorance is not an excuse. Those that plagiarized and pollute academic literature include Academic staff/teaching staff, undergraduate's students, postgraduate's students, experts in their own field, media personnel, writers amongst others. In line with the above, the common effect of plagiarism include, falling standard of education which result into incompetent graduates, decrease in creativity \& productivity, further promotion of cheating in academia, creation of a generation of academically unsound individuals, encouragement of degree holders to plagiarize and lack of awareness of the need for genuine academic research [27]. In addition, it has also pointed out that plagiarism will affect the corporate image of the entire educational system if adequate measures like suspension of studentship, termination of studentship amongst others were not taken into consideration [28].

\subsection{Perceived Measures Towards Curbing Plagiarism Among Final Year Students}

Studies on how plagiarism can be curbed among undergraduates during project writing have also been documented. In order to reduce or curb plagiarism among final year undergraduates, academic institutions all over the world should reinforce the teaching of research method, academic discourse and related rules and regulations [2]. The author further stressed that plagiarism test should be run for finished projects, project workshop be mounted for students and also, there is a need to explain to students and lecturers what plagiarism really is and what it is not. According to Marshall, Taylor, Hothersall, and Pérez-Martín, strong punishments from the institution and best approaches from lecturers are significant for preventing plagiarism [29]. In addition, Ramzan, Munir, Siddique and Asif posited that increase in knowledge and awareness on plagiarism among students can be used to control the act [30]. In the same vein, Batane stressed that advising students on using antiplagiarism software such as Turnitin to detect plagiarism in their work before submission can also serve as measure towards controlling plagiarism among students [31].

It was also pointed out that that plagiarism can be curbed among tertiary institutions students when the management of academic institutions acquire and implement good commercial plagiarism detection software and also make sure they implement, convey, and decree a viable law concerning plagiarism and any other methods of academic misconduct/dishonesty [5]. In addition, Sibomana, Ndayambaje and Uwambayinema have documented some strategies by which plagiarism can be curbed among students [32]. According to them, this act can be eradicated by solidifying reading culture among students, teaching students on research writing skills, dissemination of appropriate policy and guidelines on plagiarism among academic institutions and making use of technological knowhow in detecting plagiarism in any academic/research work. On the final note, Garba, in his study stressed that in order to avoid plagiarism among final year students, there is the need for proactive awareness campaigns and training on how to make use of plagiarism checker, such as Turnitin amongst others by the University management [33].

\subsection{Objectives of the Study}

This study was designed to investigate the perceptions of academic staff on the causes of plagiarism in project writing 
among final year undergraduates in Southwest Nigeria. Specifically, this study seeks to:

Find out the perception of academic staff on the causes of plagiarism in project writing among final year undergraduates in Southwest Nigeria.

Find out the perception of academic staffs on the effect of plagiarism on final years undergraduates in Southwest Nigeria.

Find out measures by which plagiarism can be curbed among final year undergraduates in Southwest Nigeria during project writing.

\subsection{Research Hypotheses}

There is no significant difference in the perception of lecturers from State, Federal and Private university on the causes of plagiarism in project writing among final year undergraduates.

There is no significant gender difference in the perception of lecturers on the causes of plagiarism in project writing among final year undergraduates.

\subsection{Southwest Nigeria}

Nigeria as a country, which consists of 36 states is divided into six (6) geopolitical zone namely: South South, South East, South West, North East, North Central and North West. Each of these zones consists of at least over 5 states. The Southwest which is the focus of this study consists of six (06) States. This includes Ondo, Oyo, Ekiti, Osun, Lagos and Ogun State. In each of the State, there exist at least one (01) Federal University, two (02) or more State Universities and at least two (02) or more Private Universities. Southwest is majorly, a Yoruba-speaking region. In this Yoruba speaking region of Nigeria, people abound with different dialects in form of Yoruba language. All the States in Southwest Nigeria also have common weather conditions throughout the year (Temperature ranges from $21-34^{\circ} \mathrm{C}$ ). The climate is tropical in nature and it is characterised by rain season from March to November and a dry season from November to February. Southwest, Nigeria is situated in between Edo and Delta States in the eastern region, Kwara and Kogi States, in the northern region, Republic of Benin in the Western region and in the South by the Gulf of Guinea [34].

\section{Research Methodology}

In this study, the researchers adopted the descriptive survey research method. The population consisted of all the academic staff in the exiting Private, State and Federal Universities in Southwest, Nigeria. Southwest, Nigeria is made of six (06) States (Ogun, Osun, Oyo, Ekiti, Lagos and Ondo). Purposive sampling method was adopted in selecting one Private, one State and one Federal university in each State that make up Southwest, Nigeria. In each of these six (06) States, three universities each were purposively selected in each State based on years of establishment taking into consideration one State, one Federal and one Private University. Hence, in all, 6 private universities, 6 public universities and 6 federal universities were selected making a total of eighteen (18) universities in all. In each university, one hundred (100) academic staff were randomly selected to make a total sample of 1800 academic staff in all.

The research instrument used for this study was a self designed structured questionnaire which was designed personally by the researchers and guided by literature and some experts in this field. The name of the instrument was titled Academic Staff Plagiarism Perception Questionnaire (ASPPQ). The researchers of this study make use of questionnaire which was divided into section $\mathrm{A}$ and $\mathrm{B}$. Section A was the demographic information scale (DIS), which elicited information on the respondent's geopolitical zone, gender, age, work experience, status and educational qualification. Section B was titled plagiarism perception scale (PPS). The scale sought information on the perception $\mathrm{s}$ of academic staff on causes of plagiarism in project writing, effect of plagiarism and measures by which plagiarism can be curbed. The instrument was validated by two (02) senior librarians and two (2) professors in the Department of Arts and social science education, Faculty of Education Olabisi Onabanjo University. A trial test of the instrument was conducted on 30 academic staff at the Tai Solarin University of Education, Nigeria. An alpha reliability co-efficient of 0.88 was reported.

In all the one thousand eight hundred (1800) copies of questionnaire distributed, only thousand seven hundred \& fifty seven (1757) were retrieved. This accounted for about $97.6 \%$ rate of return. Data collected was analysed with the aid of SPSS version 22.0 for window using descriptive statistics (simple percentage, mean, and standard deviation) and inferential statistics (T-test and analysis of covariance) at 0.05 levels of significance.

\section{Data Analysis and Interpretation}

\begin{tabular}{lll}
\multicolumn{2}{c}{ Table 1. Demographic Characteristics of Respondents. } \\
\hline Parameter & Frequency & Percentage \\
\hline Sex & & \\
Male & 1130 & 64.3 \\
Female & 627 & 35.7 \\
Total & 1757 & 100.0 \\
Age Group & & \\
$<$ 30 years & 113 & 6.4 \\
30-39 years & 398 & 22.7 \\
40-49 years & 765 & 43.5 \\
50-59 years & 368 & 20.9 \\
60 years and above & 113 & 6.4 \\
Total & 1757 & 100.0 \\
Status & & \\
Graduate Assistant & 48 & 2.7 \\
Assistant Lecturer & 345 & 19.6 \\
Lecturer II & 569 & 32.4 \\
Lecturer I & 282 & 16.1 \\
Senior Lecturer & 285 & 16.2 \\
Readers & 169 & 9.6 \\
Professor & 59 & 3.4 \\
Total & 1757 & 100.0 \\
Work Experience & & \\
0-5 years & 341 & 19.4 \\
\hline
\end{tabular}




\begin{tabular}{lll}
\hline Parameter & Frequency & Percentage \\
\hline 6-10 years & 287 & 16.3 \\
11-15 years & 565 & 32.2 \\
16-20 years & 452 & 25.7 \\
Above 20 years & 112 & 6.4 \\
Total & 1757 & 100.0 \\
\hline
\end{tabular}

Table 1 present the distribution of respondents according to gender, age, designation/status and years of work experience of lecturers/academic state in private, sate and federal universities in Southwest Nigeria. Findings indicated that male gender dominated the study group. In terms of the age group, majority were between 40-49 years of age. Similarly, lecturers II also dominated the study population. In terms of work experience, majority of the academic staff had between 11-15 years of work experience.

\subsection{Answers to Purpose of the Study}

One: Find out the perception of academic staff on the causes of plagiarism in project writing among final year undergraduates in Southwest Nigeria

Table 2. Perceived Causes of Plagiarism in Project writing.

\begin{tabular}{|c|c|c|c|c|c|c|c|}
\hline $\mathbf{S} / \mathbf{N}$ & Causes of Plagiarism & $\begin{array}{l}\text { Strongly } \\
\text { Agree }\end{array}$ & Agree & Disagree & $\begin{array}{l}\text { Strongly } \\
\text { Disagree }\end{array}$ & Mean & STD \\
\hline 1 & Laziness on the part of students & $913(52.0 \%)$ & $534(30.4 \%)$ & $197(11.2 \%)$ & $113(6.4 \%)$ & 3.28 & .901 \\
\hline 2 & Lack of knowledge about plagiarism & $741(42.0 \%)$ & $706(40.2 \%)$ & $225(12.8 \%)$ & $85(4.8 \%)$ & 3.19 & .840 \\
\hline 3 & Aiming to score high mark in project writing & $684(38.9 \%)$ & $849(48.3 \%)$ & $112(6.4 \%)$ & $112(6.4 \%)$ & 3.19 & .818 \\
\hline 4 & Inexperienced of students in producing source-based writing & $623(35.5 \%)$ & $709(70.4 \%)$ & $397(22.6 \%)$ & $28(1.6 \%)$ & 3.09 & .797 \\
\hline 5 & Lack of adequate skill to write final year project & $398(22.7 \%)$ & $963(54.8 \%)$ & $199(11.3 \%)$ & $197(11.12 \%)$ & 2.89 & .881 \\
\hline 6 & Poor academic planning & $457(26.0 \%)$ & $762(43.4 \%)$ & $369(22.2 \%)$ & $142(8.1 \%)$ & 2.87 & .891 \\
\hline 8 & Poor time management & $515(29.3 \%)$ & $679(38.6 \%)$ & $339(193 . \%)$ & $224(12.7 \%)$ & 2.85 & .986 \\
\hline 9 & Easy access to electronic information resources & $342(19.5 \%)$ & $848(48.3 \%)$ & $481(27.4 \%)$ & $86(4.8 \%)$ & 2.82 & .796 \\
\hline 10 & Lack of information literacy instructions & $227(12.9 . \%)$ & $768(43.5 . \%)$ & $626(35.6 . \%)$ & $140(8.0 \%)$ & 2.61 & .809 \\
\hline 11 & Fear of Failure & $287(16.3 \%)$ & $562(32.0 \%)$ & $652(37.1 \%)$ & $256(14.6 \%)$ & 2.50 & .932 \\
\hline 12 & Lack of understanding of research work & $1136.4(. \%)$ & $708(40.3 \%)$ & $595(33.9 \%)$ & $341(19.4 \%)$ & 2.34 & .861 \\
\hline
\end{tabular}

$\mathrm{N}=1757$; Criterion Mean=2.50; Weighted Mean=2.87.

In Table 2 above, academic staffs across eighteen (18) universities comprising of six (06) Private Universities, six (06) State Universities and six (06) Federal Universities in Southwest, Nigeria were asked to indicate their perceptions on the causes of plagiarism in project writing among undergraduate on a four-point Likert using 12 constructs. Their perception on the causes of plagiarism was ranked highest on Laziness on the part of students $(\bar{x}=3.28)$ followed by Lack of knowledge about plagiarism $(\bar{x}=3.19)$ and aiming to score high mark in project writing $(\bar{x}=3.19)$. This was followed by inexperienced of students in producing source-based writing $(\bar{x}=3.09)$. The least ranked in a descending order were easy access to electronic information resources $(\bar{x}=2.82)$, and followed by Lack of information literacy instructions $(\bar{x}=2.61)$. Using the criterion mean $(\bar{x}$ $=2.50)$ against the weighted mean $(\bar{x}=2.87)$ as benchmark to determine the perception of academic staff on the causes of plagiarism, one can therefore submitted that academic staff had moderate level of perception on the causes of plagiarism in project writing among undergraduate.

Two: Find out the perception of academic staffs on the effect of plagiarism on final years undergraduates in Southwest Nigeria.

Table 3. Perceived effect of plagiarism.

\begin{tabular}{|c|c|c|c|c|c|c|c|}
\hline $\mathbf{S} / \mathbf{N}$ & Effect of Plagiarism & $\begin{array}{l}\text { Strongly } \\
\text { Agree }\end{array}$ & Agree & Disagree & $\begin{array}{l}\text { Strongly } \\
\text { Disagree }\end{array}$ & Mean & STD \\
\hline 1 & Plagiarism can lead to production of incompetent graduate & $851(48.4 \%)$ & $680(38.7 \%)$ & $114(6.5 \%)$ & $112(6.4 . \%)$ & 3.29 & .848 \\
\hline 2 & Plagiarism can lead to failure in the subject (final year project) & $735(41.8 \%)$ & $740(42.1 \%)$ & $141(8.0 \%)$ & $141(8.0 \%)$ & 3.18 & .888 \\
\hline 3 & Plagiarism can lead to injustices in grading students projects & $710(40.2 \%)$ & $707(40.2 \%)$ & $256(14.6 \%)$ & $84(4.8 \%)$ & 3.16 & .846 \\
\hline 4 & Plagiarism can lead to disciplinary probation from the school & $597(34.0 \%)$ & $766(43.6 \%)$ & $254(14.5 \%)$ & $140(8.0 \%)$ & 3.04 & .896 \\
\hline 5 & Plagiarism can lead to expulsion of students from school. & $653(37.2 \%)$ & $596(33.9 \%)$ & $368(20.9 \%)$ & $140(8.0 \%)$ & 3.00 & .949 \\
\hline 6 & Plagiarism can lead to suspension of studentship & $569(32.4 \%)$ & $596(33.9 . \%)$ & $424(24.1 \%)$ & $168(9.6 . \%)$ & 2.89 & .968 \\
\hline
\end{tabular}

$\mathrm{N}=1757$; Criterion Mean=2.50; Weighted Mean=3.06.

Result presented in Table 3 above indicates the perception of academic staff of the effect of plagiarism among final year student in Southwest Nigeria. From the above, the perception of academic staff was ranked highest on the statements that read "Plagiarism can lead to breeding of incompetent graduate" ( $\bar{x}=3.29$ ), followed by Plagiarism can lead to failure in final year project ( $\bar{x}=3.18$ ), then by Plagiarism can lead to injustice in grading students projects $(\bar{x}=3.16)$. The least ranked perception of academic staff on the effect of plagiarism was that plagiarism can discouraged students from understanding research work $(\bar{x}=2.82)$

Three: Find out measure by which plagiarism can be curbed among final undergraduates in Southwest Nigeria during project writing. 
Table 4. Measure by which plagiarism can be curbed among final year Undergraduates.

\begin{tabular}{|c|c|c|c|c|c|c|c|}
\hline $\mathbf{S} / \mathbf{N}$ & Solution to Plagiarism & $\begin{array}{l}\text { Strongly } \\
\text { Agree }\end{array}$ & Agree & Disagree & $\begin{array}{l}\text { Strongly } \\
\text { Disagree }\end{array}$ & Mean & STD \\
\hline 1 & $\begin{array}{l}\text { The university should create awareness on plagiarism and its } \\
\text { effects }\end{array}$ & $1164(66.2 \%)$ & $565(32.2 \%)$ & $28(1.6 \%)$ & $0(0.0 \%)$ & 3.65 & .510 \\
\hline 2 & $\begin{array}{l}\text { Talks, seminar and workshops should be conducted regularly on } \\
\text { plagiarism at departmental, faculty and university level in general }\end{array}$ & $1079(61.4 \%)$ & $622(35.4 \%)$ & $28(1.6 \%)$ & $28(1.6 \%)$ & 3.57 & .611 \\
\hline 3 & $\begin{array}{l}\text { Use of plagiarism software should be introduced and made freely } \\
\text { accessible for use by students and lecturers }\end{array}$ & $1165(66.3 \%)$ & $452(25.7 \%)$ & $112(6.4 \%)$ & $28(1.6 \%)$ & 3.57 & .685 \\
\hline 4 & $\begin{array}{l}\text { Plagiarism software should be use often by the supervisor to check } \\
\text { students project }\end{array}$ & 1077 (61.3\%) & $567(32.3 \%)$ & $85(4.8 \%)$ & $28(1.6 \%)$ & 3.53 & .665 \\
\hline 5 & $\begin{array}{l}\text { Supervisor should request students to submit literature matrix on } \\
\text { related articles }\end{array}$ & $824(46.7 \%)$ & $821(46.7 \%)$ & $84(4.8 \%)$ & $28(1.6 \%)$ & 3.39 & .655 \\
\hline 6 & $\begin{array}{l}\text { Supervisor should make sure student underline materials used and } \\
\text { must be shown for clarifications }\end{array}$ & 797 (45.4\%) & $848(48.3 \%)$ & $56(3.2 \%)$ & $56(3.2 \%)$ & 3.36 & .696 \\
\hline 7 & Students should be taught on how to reference materials used. & $994(56.6 \%)$ & $539(30.7 \%)$ & & $140(8.0 \%)$ & 3.36 & .897 \\
\hline 8 & Measures should be put in place to sanction the offenders & $765(43.5 \%)$ & $768(43.7 \%)$ & $168(9.6 \%)$ & $56(3.2 \%)$ & 3.28 & .763 \\
\hline 9 & Project topic should be given to students by their supervisor (s) & $400(22.8 \%)$ & $397(22.6 \%)$ & $594(33.8 \%)$ & $366(20.8 \%)$ & 2.47 & 1.059 \\
\hline 10 & $\begin{array}{l}\text { Students should be discouraged from chosen project topic on their } \\
\text { own }\end{array}$ & $429(24.4 \%)$ & $283(16.1 \%)$ & $567(32.3 \%)$ & $478(27.8 \%)$ & 2.38 & 1.126 \\
\hline
\end{tabular}

$\mathrm{N}=1757$; Criterion Mean=2.50; Weighted Mean=3.26.

Table four present the distribution based on the perception of academic staff on the solution towards eradicating plagiarism in project writing among final year undergraduates in Nigeria. Findings revealed that plagiarism can be curbed though the followings: awareness campaign by the university on plagiarism and its effects, Talks, seminar and workshops on plagiarism at departmental, faculty and university level in general, introduction of freely accessible plagiarism software for use by students and lecturers, Plagiarism software should be use often by the supervisor to check students project, Supervisor should request students to submit literature matrix on related articles, Supervisor should make sure student underline materials used and must be shown for clarifications, Students should be taught on how to reference materials used and measures should be put in place to sanction the offenders.

\subsection{Answer to Research Hypotheses}

One: There is no significant difference in the perception of lecturers from State, Federal and Private university on the causes of plagiarism in project writing among final year undergraduates.

Table 5. One way Analysis of Variance (ANOVA) showing difference in the perception of lecturers of causes of plagiarism by school type.

\begin{tabular}{lllllll}
\hline & N & Mean & $\begin{array}{l}\text { Std. } \\
\text { Deviation }\end{array}$ & $\begin{array}{l}\text { Std. } \\
\text { Error }\end{array}$ & F-Cal & Probability \\
\hline State & 653 & 35.4824 & 3.69485 & .14459 & & \\
Federal & 566 & 34.9152 & 5.01713 & .21089 & 45.023 & 0.000 \\
Private & 538 & 32.8922 & 5.81236 & .25059 & & \\
Total & 1757 & 34.5065 & 4.97048 & .11858 & & \\
\hline
\end{tabular}

Result presented in table 5 indicate a significant (i.e $\mathrm{F}=45.023 ; \mathrm{P}<0.05)$. This outcome implies that the perception of academic staff in state universities on the causes of plagiarism in project writing among final year undergraduates differs significantly from that of federal and private universities respectively.

Two: There is no significant gender difference in the perception of lecturers on the causes of plagiarism in project writing among final year undergraduates.

Table 6. Independent Sample t-test showing gender differences in the perception of academic staff of the causes of plagiarism.

\begin{tabular}{lllllll}
\hline Gender & N & Mean & Std. Deviation & Std. Error Mean & t-Cal & Probability \\
\hline Male & 1130 & 34.5133 & 4.27657 & .12722 & 0.076 & 0.939 \\
Female & 627 & 34.4944 & 6.02640 & .24067 & 0.076 & \\
\hline
\end{tabular}

The result in Table 6 revealed a non-significant outcome $(\mathrm{t}=0.076 ; \mathrm{p}>0.05)$. The outcome implied no significant gender difference in the perception of male and female lecturers on the causes of plagiarism in project writing among final year undergraduates in southwest Nigeria. Hence, the null hypotheses is hereby accepted.

\section{Discussions of Findings}

Findings of this study indicated amongst others that laziness on the part of students, lack of knowledge about plagiarism, aiming to score high mark in project writing, inexperienced of students in producing source-based writing and lack of adequate skill to write final year project were some of the perceived causes of plagiarism in project writing among undergraduates'. The reason for this is that majority of our undergraduates this day are lazy and the only things they want is money. Not only that, information explosion through easy accessibility of internet had also made it easier for them to plagiarize. Findings above corroborate with earlier findings [15-17]. According to them, laziness on part of final year students coupled with their ignorance about 
plagiarism make them to plagiarize while writing their final year project. Findings were also accordance with the work of ${ }^{5}$. According to the authors', the desire to achieve high marks, fear of failure and poor academic planning among many others reason make plagiarism possible among undergraduates. Findings further corroborate with other researchers $[12,19,21,22]$. They specifically pointed out that easy access to internet, laziness on the part of students, and the desire to score high mark in subject matter give room for plagiarism among students.

On the adverse effect of plagiarism, findings pointed out that it can lead to breeding of incompetent graduates, failure in the subject (final year project), give room for to injustice in grading student's projects, probation, suspension and possibly determination/expulsion of studentship from the university environment. This is the most reason why some graduate of nowadays find it difficult to secure a good job because of incompetency that could not allow them scale through job interview talkless of coping with tasking white collar job. Supporting the above findings was the study carried out by Ennam [27]. According to his findings, the common effect of plagiarism includes breeding of incompetent graduates, creation of a generation of academically unsound individuals, amongst others. Similarly, findings corroborate with that of Salleh, Ghazali, Awang, and Sapiai, who pointed out that failure to put in place adequate measures like suspension of studentship, termination of studentship among others will jeopardize the corporate image of the entire educational system as a result of incessant plagiarism that is common among undergraduates at all levels [28].

Consequently, on the measures by which plagiarism can be curbed among final year undergraduates in project writing, findings of this study indicated that awareness campaign, regular talks/seminars and workshops on the subject matter, use of plagiarism checker, materials submission to supervisors among others were some of the perceived measures that can be adopted in solving the menace of plagiarism among students. The above corroborate with the findings of Ramzan, Munir, Siddique, and Asif and Garba who posited that increase in knowledge and awareness campaign and training on plagiarism among students can be used to control the act [30, 33]. Similarly, findings of this study were in consonant with the work of other researchers who advocate the use of anti-plagiarism software such as Turnitin to detect plagiarism in students work/project before submission can also serve as a measure towards controlling plagiarism among students $[5,31,32]$.

On the final note, findings based on the hypotheses indicated that there is a significant difference in the perception of lecturers from State, Federal and Private universities on the causes of plagiarism in project writing among final year undergraduates. Moreso, findings also revealed that there is no significant gender difference in the perception of lecturers on the causes of plagiarism in project writing among final year undergraduates.

\section{Conclusion}

In conclusion, there is need for collective efforts of students, lecturers, university management as well as the government in making sure that plagiarism and any form of academic misconduct is totally eradicated from our educational system. Aside from polluting the literature, plagiarism dents the image of the system and therefore should be handled as a matter of utmost concern. On the part of students, they need to be determined within themselves and ready to learn how-to avoid plagiarism of any kind. To lecturers, they need to be trained and re-trained so as to be able to trained their students well and make sure they understand research methodology as well as how to conduct research void of plagiarism. Not only that, lecturers also need to turnitin every project they supervise before appending their signature for future references. For universities managements (Private, State and Federal), plagiarism software must be made available for free usage among the teachers and students as at when due. On the part of the government, they should support education through funding so as to put in place all that is needed by the educational system to fight against any form of academic dishonesty.

\section{Recommendations}

In line with the findings of this study, it is thus recommended that:

The management of tertiary institutions should as a matter of urgency procure plagiarism software that can be use in checking final year project before final approval and submissions by the students.

Final year students should be introduced to webinar training that focus more about writing a research project void of plagiarism

Research methodology courses taught at various levels should be handled by experienced lecturers while contents like literature searches, writing skills, referencing style should also be included in the curriculum. Assignments like choosing a researchable topic, conducting the research and reporting the findings of the study should also form part of the continuous assessment of such courses.

There is need for proactive training among undergraduates on plagiarism. This training should involved teaching students on how to reference any consulted materials.

Seminars /Talks as well as workshops of plagiarism and others academic integrity should be conducted regularly for members of the university community, most especially, the final year students.

Materials use in writing project should be shown to project supervisors and if need be, students should point out some specific area used and how they reference it for clarifications.

Students should be discouraged in contracting their project out.

Any student find plagiarized should be sanctions. This could include suspension, determination of studentship or even withdrawal of studentship from the university. This will serve as a warning to others. 


\section{References}

[1] Haworth, G. M. Student projects: plagiarism and assessment. In: JISC 2nd International Plagiarism Conference, 19th - 21st May, 2006, The sage, Gateshead, Newcastle. 2006, Available at http://centaur.reading.ac.uk/4558/.

[2] Emenalo, F. C. Management Strategies for Curbing the Prevalence of Plagiarism in Project Writingamongst Students of Imo State University Oweeri. Universal Journal of Educational Research., 2016, 4 (9), 1965-1972.

[3] Wan, R., Nordin, S. B., Halib, M. B., \&Ghazali, Z. B. Plagiarism among Undergraduate Students in an EngineeringBased University: An Exploratory Analysis. European Journal of Social Sciences; 2011, 25 (4), 80-96.

[4] Olesen, A. P, Amin, L.\&Mahadi, Z. Researchers experience of misconduct in research in Malaysian higher education institutions. Accountability in Research., 2018, 25 (3): 125-14.

[5] Buraimo, O., Olusanya, F, O., Oyedokun, S. O \&Adekunmisi, R. A. Plagiarism Perceptions among Undergraduates at OlabisiOnabanjo University, Nigeria. South African Journal of Information Studies., 2019, 37 (4): 1-23. https://doi.org/10.25159/2663-659X/6409.

[6] Awasthi, S. Plagiarism and Academic Misconduct: A Systematic Review. DESIDOC Journal of Library and Information Technology., 2019, 39 (2) 94-100. doi: 10.14429/djlit.39.2.13672.

[7] Babalola, Y. T. Awareness and incidence of plagiarism amongundergraduates in a Nigerian private university. African Journal of Library, Archives and Information Science., 2012, 22 (1) 53-60.

[8] Baysen, F, Çakmak, N. \&Özsavaş-Akçay, A. Architecture students' attitudes towards plagiarism". BilgiDünyası., 2018, 19 (2), 231-253. doi: 10.15612/BD.2018.719.

[9] Kayaoğlu M. N., Erbay, S., Flitner, C. C., \&Saltaş, D. Examining Students' Perceptions of Plagiarism: A Crosscultural Study at Tertiary Level. Journal of Further and Higher Education., 2015, http://dx.doi.org/10.1080/0309877x.2015.1014320.

[10] Soyemi, O. D \& Ojo, A. I. Lecturers' perception and attitude towards plagiarism among students: Implications for higher education in Nigeria: Paper presented at the $3^{\text {rd }}$ School of Education and Humanities International Conference, themed, "On the Future of Higher Education in Africa", 2015, Babcock University, Ilishan, August 24th-26th.

[11] Nimasari, E. P., Gestanti, R. A., \&Mufanti, R. What University-Students Believe about Plagiarism. International Journal of Social Sciences., 2019, 4 (3), 1912-1925.

[12] Anney, V. N. \&Mosha, M. A. Student's Plagiarisms in Higher Learning Institutions in the Era of Improved Internet Access: Case Study of Developing Countries. Journal of Education and Practice., 2015, 6 (13): 203-216.

[13] Seadle, M. Copyright in the networked world: plagiarism and its ambiguities. Library Hi Tech., 2008, 26, 4, 691-695.

[14] Louch, M. O-B. Teaching Case Single Sourcing, Boilerplates, and Re-Purposing: Plagiarism andTechnical Writing. Information Systems Education Journal., 2016, 14 (2), 27-33.
[15] Bal, K. S. Plagiarism Among University Students: Intentional or Accidental. Journal of NELTA., 2007, 12: 1-2.

[16] Nwana, O. C. University Academics in Nigeria, Memoirs of an Insider, Owerri: Peace Wise., 2008. 178-179.

[17] Awujo C. G. Research Anxiety Among Education Undergraduates. African Journal of Higher Education Studies and Development., 2013, 3, 33-42.

[18] Honing, B. \&Bedi, A. The fox in the hen house: a critical examination of plagiarism among members of the Academy of Management. Academy of Management, Learning and Education., 2012, 11 (1), 101-123.

[19] Armstrong, L. (2008). Final year undergraduate student plagiarism: academic staff and student perceptions. Luke Armstrong Graduate, 7 (3); 16-20.

[20] Sentleng, M. P., \& King, L. Plagiarism among undergraduate students in the Faculty of Applied Science at a South African Higher Education Institution. SA Jnl Libs \& Info Sci., 2012, 78 (1): 57-68.

[21] Graham-Matheson, L. \& Starr, S. Is it cheating or learning the craft of writing? Using Turnitin to help students avoid plagiarism. Research in Learning Technology. Research in Learning Technology., 2013, 21, 1-13.

[22] Jereb, E, Perc, M., LaĖmmlein, B., Jerebic, J, Urh, M \& Podbregar, I. Factors influencing plagiarism in higher education: A comparison of German and Slovene students". PLoS ONE., 2018, 13 (8), 16.

[23] Betts, L. R., Bostock, S. J., Elder, T. J., \&Trueman, M. Encouraging good writing practice in first-year Psychology students: An intervention using Turnitin. Psychology Teaching Revie., 2012, 18 (2), 74-81.

[24] Hayes, N. \&Introna, L. D. Cultural values, plagiarism and fairness: When plagiarism gets in the way of learning. Ethics and Behavior., 2015, 15 (3), 213-231.

[25] Power, L. G. University Students' Perceptions of Plagiarism". The Journal of Higher Education., 2009, 80 (6): 643-662.

[26] Cleary, M. N. Top ten reasons students plagiarize and what you can do about it, 2012, Retrieved 21st May, 2020fromhttps://offices.depaul.edu/oaa/facultyresources/teaching/academicintegrity/Documents/Top\%20Ten\%20Reasons\%20Students\%2 0Plagiarize $\%$ pdf.

[27] Ennam, O. Systematic Analysis of the Effects of Digital Plagiarism on Scientific Research: Investigating the Moroccan Context - IbnTofail University as Case Study. Journal of Education and Practice., 2018, 8 (2): 133-141.

[28] Salleh, M. I. M., Ghazali, S. A. M., Awang, Z\&Sapiai, N. S. The Effect of Plagiarism on the Corporate Image in the Higher Education: An Extended TPB Model. International Journal of Social Science and Humanity., 20122 (4): 340-344.

[29] Marshall, T., Taylor, B., Hothersall, E., \& Pérez-Martín, L. Plagiarism: a case study of quality improvement in a taught postgraduate programme. Medical Teacher., 2011, 33 (7), 375-381.

[30] Ramzan, M., Munir, M. A., Siddique, N., \&Asif, M. Awareness about plagiarism amongst universitystudents in Pakistan. Higher education., 2012, 64 (1), 73-84. 
[31] Batane, T. Turning to Turnitin to fight plagiarism among university students. Journal of EducationalTechnology\& Society., 201013 (2), 1-10.

[32] Sibomana, E., Ndayambaje, I., \&Uwambayinema, E. Plagiarism in higher education environment: causes and solutions. Rwandan Journal of Education., 2018, 4 (2), 15-24.

[33] Garba, K. D. Awareness and Perception of Academicians on the Use of Turnitin Software in Detecting Plagiarism in Bayero University Kano. African Journal of Education, Science and Technology., 2018, 5 (1) 1-9.

[34] Faleyimu, O. I., Agbeja, B. O. \& Akinyemi, O. State of forest regeneration in Southwest Nigeria. African Journal of Agricultural research., 2013, 8 (26), 3381-3383. https://doi:10.5897/AJAR09.035. 